\title{
Comparative analysis of health problems in students from elementary school and middle school in Lublin, 2010-2015
}

\author{
KATARZYNA KOCKA ${ }^{1, A-F}$, BARBARA ŚLUSARSKA ${ }^{1, D, G}$, AGNIESZKA BARTOSZEK ${ }^{1, c}$, MARCIN \\ RZACCA $^{2, c}$, URSZULA ZDYBEL-FAtDYGA ${ }^{3, B}$, GRZEGORZ NOWICKI ${ }^{1, F}$, KATARZYNA NAYLOR ${ }^{4, E}$
}

${ }^{1}$ Department of Family Medicine and Community Nursing, Chair of Oncology and Environmental Health, Faculty of Health Sciences, Medical University of Lublin, Poland

2 Department of Oncology Chair of Oncology and Environmental Health, Faculty of Health Sciences,

Medical University of Lublin, Poland

${ }^{3}$ Health Care Center of School Medicine "TERMED" in Lublin, Poland

${ }^{4}$ Department of Didactics and Medical Simulation, Chair of Human Anatomy, I Faculty of Medicine,

Medical University of Lublin, Poland

A - Study Design, B - Data Collection, C - Statistical Analysis, D - Data Interpretation, E - Manuscript Preparation, F - Literature Search, G - Funds Collection

Summary Background. The results of the European Health Interview Surveys, performed in 2014, has indicated that every fourth child in Poland has long-term health problems or chronic diseases.

Objectives. Diagnosis and comparison of the most common health problems occurring among children attending primary and middle school.

Material and methods. The study has an epidemiological cross-sectional character, and it is concerned with health problems in the Lublin primary and middle school population. The source of data was secondary materials derived from the statistical reporting documentation "Collective analysis of students' health status", covering the years 2010-2015 and conducted by a nurse of the teaching and learning environment under contract with the National Health Fund.

Results. Health problems were diagnosed in $44.3 \%(n=846)$ of primary school students and $50.6 \%(n=804)$ of middle school students. Excessive body weight and endocrine disorders and eye diseases are significantly more common in the middle school students than in primary school children $(p<0.001)$. In contrast, younger children are more likely to be diagnosed with hearing and speech disorders $(p<0.001)$ and increased incidence of injuries $(p<0.05)$.

Conclusions. The frequency of health disorders increases with the age of the students. The predominant health problem among both primary school and middle school students is defects and diseases of the motor organs. The most common chronic diseases diagnosed among school children are allergic diseases. Accidents and injuries are the most common health risks to the developmental age population.

Key words: students, primary schools, middle schools, public health.

Kocka K, Ślusarska B, Bartoszek A, Rząca M, Zdybel-Fałdyga U, Nowicki G, Naylor K. Comparative analysis of health problems in students from elementary school and middle school in Lublin, 2010-2015. Fam Med Prim Care Rev 2018; 20(1): 7-12, doi: https://doi. org/10.5114/fmpcr.2018.73697.

\section{Background}

Monitoring of the health status of the population in the developmental age enables early detection of disorders of the body function and the programming and implementation of corrective actions leading to the minimization of diagnosed health dysfunctions. This is a significant preventive measure because, according to the European Health Survey (EHIS) of 2014, every fourth child in Poland has long-term health or chronic illnesses [1]. The HBSC Report (Health Behavior in School-aged Children) confirmed the severity of the occurrence of a number of indicators related to morbidity in a group of school children and emphasized a significant increase in the prevalence of somatic symptoms, such as headaches, abdominal pain or back pain [2]. The data available in literature confirms that young people undertake risky behaviors, such as addictive substances, low levels of physical activity or irregular consumption of foods, that result in increased health problems. Research conducted by the Food and Nutrition Institute (FNI) clearly indicates the existence of the problem of excessive weight gain in children and adolescents of school age. Overweight and obesity diagnosed during childhood increases the risk of metabolic diseases. The health consequences of overweight are rarely observed in young people, but they relate to $70-80 \%$ of the adult population, who gained weight during their adolescence [3]. In addition, changing socio-economic and environmental factors contribute to the increase of civilizational diseases diagnosed in children and adolescents, increasing the risk of carbohydrate-lipid disorders as well as allergic diseases [4]. This is confirmed by Szymborski's analysis of the health status of children and adolescents, where in a population of $0-14$ years $(n=5,783)$, almost $31 \%$ of the patients had at least one chronic disease or condition. For comparison, in 2004, chronic diseases were reported in $22.4 \%$ of children. In the youth group ( $n=2446.3$ thousand) aged 15-19 , long-term health problems were reported in $20.5 \%$ of the population, where in 2004 , health problems were found in less than $15 \%$ of the youth. Among chronic diseases diagnosed both in children and adolescents, the most common ones were aller- 
gies ( $17 \%$ and $11 \%$, respectively) [5]. Therefore, improving the health of children and adolescents should be a priority for the health policy of the state, based on sound scientific research. The above postulation is in line with the World Health Organization (WHO), which identifies health goals for Europe in the Health 2020 program, highlighted the importance of reduction in health inequalities and the campaign of health promotion. However, detailed diagnosis concerning the existing health situation and major threats is needed to define specific targets in each country, as well as for identification of the target groups to which prevention and intervention will be directed. As indicated by the WHO, the health of children is crucial in determining trends in the health of society as a whole, as the body and health behaviors shaped during the developmental age influence adult life [6]. Diagnosis of the actual health situation of children and adolescents is a basis for defining health care priorities and undertaking coordinated and planned preventive actions [7]. In the school environment, comprehensive nursing care is provided by a nurse in the teaching and learning environment, whose responsibilities include systematically performing and interpreting screening tests, which allows for early diagnosis of health disorders. The presented analysis of health problems among primary school and middle school students will enable medical staff to undertake targeted preventive and promotional activities in the school environment.

In literature, there is no national data reporting the results of the screening test concerning pupils enrolled in preventive health care in the educational environment. Few studies present the results of analyses covering chosen macro-regions of Poland [7-10].

Analysis of the literature on the subject showed no information on the health situation of children and adolescents in the Lubelskie voivodship, thus an attempt was made to identify the health problems of the school population in the city of Lublin.

\section{Objectives}

Determining the health status of primary and middle school students by identifying and comparing the most common health problems based on the results of completed preventive examinations, including screening tests, conducted in the teaching and learning environment in the Lublin region.

\section{Material and methods}

The research is an epidemiological cross-sectional study, and it is concerned with health problems in the primary and secondary school population in Lublin. The results of screening tests were analyzed for early detection of physical developmental abnormalities, limb movement disorders, visual and auditory defects and information about acquired medical conditions and diseases and other events affecting the health of the student. The project was to analyze the student data of a selected school located in the Lublin region under the care of the Non-public Health Care Center of School Medicine "TERMED" in Lublin. The source of data was secondary materials derived from the statistical reporting documentation "Collective analysis of students' health status", covering the years 2010-2015 and conducted by a nurse of the teaching and learning environment under contract with the National Health Fund. The study used the method of retrospective analysis of documents. In total, the documentation analysis involved 4,169 primary school pupils and 1,589 middle school pupils in Lublin.

The study was conducted with the consent of the Non-public Health Care Centre of School Medicine "TERMED" in Lublin, which, under contract with the National Health Fund, performs preventive health care for pupils.

The results obtained were analyzed statistically. The values of the non-measurable parameters were presented by means of counting and percentage.

For unrelated qualities, the $\chi^{2}$ homogeneity test was used to detect the differences between the groups compared. A significance level of $p<0.05$ was established to indicate the existence of statistically significant differences. Data base and statistical studies were performed using STATISTICA 12.0 computer software (StatSoft, Poland).

Research was carried out in accordance to ethical principles of scientific research, the Declaration of Helsinki, as well as the Ethical Code of the Polish Academy of Science. School administrations were informed of the research goals, and their permission was obtained prior to starting the study.

\section{Results}

Health problems were diagnosed in $44.3 \%(n=1846)$ of primary school students and $50.6 \%(n=804)$ of middle school students. The occurrence of health problems among students in particular years is presented in Table 1.

\begin{tabular}{|c|c|c|c|c|c|c|c|c|c|c|c|c|c|c|c|c|}
\hline \multirow[t]{2}{*}{ Evaluation indicators } & \multicolumn{2}{|l|}{ School } & \multicolumn{5}{|c|}{ Primary school } & \multicolumn{5}{|c|}{ Middle school } & \multicolumn{2}{|c|}{ General } & \multicolumn{2}{|c|}{ Statistics } \\
\hline & \multicolumn{2}{|l|}{ School year } & $\begin{array}{l}\text { 검 } \\
\text { 을 } \\
\text { 을 }\end{array}$ & 국 & $\frac{m}{\stackrel{m}{7}}$ & $\frac{\vec{d}}{\mathrm{~m}}$ & $\frac{\text { मी }}{\text { ने }}$ & 검 & 국 & $\frac{m}{\frac{m}{7}}$ & $\frac{\vec{d}}{\mathrm{~m}}$ & 룰 & 츨 & 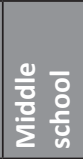 & $\chi^{2}$ & $p$ \\
\hline \multirow{2}{*}{\multicolumn{2}{|c|}{ Student health problems }} & $n$ & 350 & 429 & 397 & 325 & 345 & 213 & 143 & 183 & 152 & 113 & 1846 & 804 & \multirow[t]{2}{*}{18.4} & \multirow[t]{2}{*}{$<0.001$} \\
\hline & & $\%$ & 43 & 50 & 48 & 39 & 41 & 60 & 44 & 55 & 49 & 43 & 44.3 & 50.6 & & \\
\hline \multirow{8}{*}{$\begin{array}{l}\text { Somatic develop- } \\
\text { mental defects }\end{array}$} & \multirow{2}{*}{$\begin{array}{l}\text { low body } \\
\text { mass and } \\
\text { height }\end{array}$} & $n$ & 60 & 46 & 42 & 31 & 27 & 24 & 24 & 16 & 11 & 11 & 206 & 86 & \multirow[t]{2}{*}{0.53} & \multirow[t]{2}{*}{0.466} \\
\hline & & $\%$ & 7 & 5 & 5 & 4 & 3 & 7 & 7 & 5 & 4 & 4 & 4.9 & 5.4 & & \\
\hline & \multirow[t]{2}{*}{ overweight } & $n$ & 41 & 33 & 39 & 28 & 37 & 19 & 16 & 15 & 18 & 21 & 178 & 89 & \multirow[t]{2}{*}{4.61} & \multirow[t]{2}{*}{0.031} \\
\hline & & $\%$ & 5 & 4 & 5 & 3 & 4 & 5 & 5 & 5 & 6 & 8 & 4.3 & 5.6 & & \\
\hline & \multirow[t]{2}{*}{ obesity } & $n$ & 45 & 35 & 42 & 31 & 30 & 26 & 26 & 17 & 31 & 31 & 183 & 131 & \multirow[t]{2}{*}{33.1} & \multirow[t]{2}{*}{$<0.001$} \\
\hline & & $\%$ & 6 & 4 & 5 & 4 & 4 & 7 & 8 & 5 & 10 & 12 & 4.4 & 8.2 & & \\
\hline & \multirow[t]{2}{*}{ general } & $n$ & 146 & 114 & 124 & 90 & 94 & 69 & 66 & 48 & 60 & 63 & 568 & 306 & \multirow[t]{2}{*}{28.3} & \multirow[t]{2}{*}{$<0.001$} \\
\hline & & $\%$ & 18 & 13 & 15 & 11 & 11 & 19 & 20 & 14 & 19 & 24 & 13.6 & 19.3 & & \\
\hline \multirow{4}{*}{$\begin{array}{l}\text { Accidents and } \\
\text { injuries }\end{array}$} & \multirow[t]{2}{*}{ general } & $n$ & 40 & 43 & 45 & 40 & 32 & 14 & 22 & 12 & 12 & 8 & 200 & 68 & \multirow[t]{2}{*}{0.69} & \multirow[t]{2}{*}{0.044} \\
\hline & & $\%$ & 5 & 5 & 5 & 5 & 4 & 4 & 7 & 4 & 4 & 3 & 4.8 & 4.3 & & \\
\hline & \multirow{2}{*}{$\begin{array}{l}\text { on the } \\
\text { school } \\
\text { grounds }\end{array}$} & $n$ & 20 & 22 & 20 & 23 & 16 & 4 & 4 & 4 & 5 & 7 & 101 & 24 & \multirow[t]{2}{*}{4.51} & \multirow[t]{2}{*}{0.033} \\
\hline & & $\%$ & 2 & 3 & 2 & 3 & 2 & 1 & 1 & 1 & 2 & 3 & 2.4 & \begin{tabular}{|l|}
1.5 \\
\end{tabular} & & \\
\hline
\end{tabular}




\begin{tabular}{|c|c|c|c|c|c|c|c|c|c|c|c|c|c|c|c|c|}
\hline \multirow{2}{*}{$\begin{array}{l}\text { Evaluation indi- } \\
\text { cators }\end{array}$} & \multicolumn{2}{|l|}{ School } & \multicolumn{5}{|c|}{ Primary school } & \multicolumn{5}{|c|}{ Middle school } & \multicolumn{2}{|c|}{ General } & \multicolumn{2}{|c|}{ Statistics } \\
\hline & \multicolumn{2}{|l|}{ School year } & 굴 & 각 & $\frac{m}{\frac{m}{2}}$ & $\frac{d}{\frac{\pi}{2}}$ & $\frac{\text { in }}{\mathrm{f}}$ & 을 & 굴 & $\frac{m}{\frac{n}{7}}$ & $\frac{\substack{\mathrm{d} \\
\mathrm{m}}}{\mathrm{m}}$ & 룰 &  & 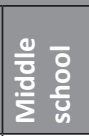 & $x^{2}$ & $p$ \\
\hline \multirow{2}{*}{\multicolumn{2}{|c|}{$\begin{array}{l}\text { Eye conditions, problems and } \\
\text { diseases }\end{array}$}} & $n$ & 128 & 139 & 126 & 120 & 126 & 78 & 75 & 68 & 66 & 66 & 639 & 353 & \multirow[t]{2}{*}{33.1} & \multirow[t]{2}{*}{$<0.001$} \\
\hline & & $\%$ & 16 & 16 & 16 & 15 & 15 & 22 & 23 & 20 & 21 & 25 & 15.3 & 22.2 & & \\
\hline \multirow{6}{*}{$\begin{array}{l}\text { Chronic diseases } \\
\text { of the hearing } \\
\text { and speech } \\
\text { organs }\end{array}$} & \multirow{2}{*}{$\begin{array}{l}\text { hearing } \\
\text { impedi- } \\
\text { ments }\end{array}$} & $n$ & 1 & 3 & 2 & 1 & 4 & 0 & 0 & 0 & 0 & 0 & 11 & 0 & \multirow[t]{2}{*}{4.20} & \multirow[t]{2}{*}{0.040} \\
\hline & & $\%$ & 0 & 0 & 0 & 0 & 0 & 0 & 0 & 0 & 0 & 0 & 0.3 & 0 & & \\
\hline & \multirow{2}{*}{$\begin{array}{l}\text { speech } \\
\text { impedi- } \\
\text { ments }\end{array}$} & $n$ & 30 & 27 & 20 & 26 & 27 & 2 & 2 & 3 & 0 & 2 & 130 & 9 & \multirow[t]{2}{*}{31.8} & \multirow[t]{2}{*}{0.004} \\
\hline & & $\%$ & 4 & 3 & 2 & 3 & 3 & 1 & 1 & 1 & 0 & 1 & 3.1 & 0.6 & & \\
\hline & \multirow[t]{2}{*}{ general } & $n$ & 31 & 30 & 22 & 27 & 31 & 2 & 2 & 3 & 0 & 2 & 141 & 9 & \multirow[t]{2}{*}{35.95} & \multirow[t]{2}{*}{$<0.001$} \\
\hline & & $\%$ & 4 & 4 & 3 & 3 & 4 & 1 & 1 & 1 & 0 & 1 & 3.4 & 0.6 & & \\
\hline \multirow{8}{*}{$\begin{array}{l}\text { Motor defects } \\
\text { and diseases }\end{array}$} & scoliosis & $n$ & 12 & 8 & 5 & 17 & 16 & 19 & 17 & 18 & 12 & 9 & 58 & 75 & 56.50 & $<0.001$ \\
\hline & & $\%$ & 1 & 1 & 1 & 2 & 2 & 5 & 5 & 5 & 4 & 3 & 1.4 & 4.7 & & \\
\hline & excessive & $n$ & 0 & 2 & 3 & 1 & 0 & 0 & 0 & 2 & 2 & 0 & 6 & 4 & 0.77 & 0.378 \\
\hline & $\begin{array}{l}\text { thoracic } \\
\text { kyphosis }\end{array}$ & $\%$ & 0 & 0 & 0 & 0 & 0 & 0 & 0 & 1 & 1 & 0 & 0.1 & 0.3 & & \\
\hline & deformi- & $n$ & 113 & 120 & 129 & 103 & 140 & 5 & 9 & 15 & 13 & 27 & 605 & 69 & 115.12 & $<0.001$ \\
\hline & $\begin{array}{l}\text { tes or the } \\
\text { knees, feet }\end{array}$ & $\%$ & 14 & 14 & 16 & 12 & 16 & 1 & 3 & 5 & 4 & 10 & 14.5 & 4.3 & & \\
\hline & general & $n$ & 242 & 210 & 235 & 201 & 226 & 87 & 94 & 97 & 66 & 83 & 1114 & 427 & 0.01 & 0.909 \\
\hline & & $\%$ & 30 & 25 & 29 & 24 & 27 & 25 & 29 & 29 & 21 & 31 & 26.7 & 26.9 & & \\
\hline Respiratory sys- & allergies & $n$ & 19 & 26 & 27 & 20 & 38 & 14 & 6 & 11 & 12 & 8 & 130 & 51 & 0.03 & 0.585 \\
\hline & & $\%$ & 2 & 3 & 3 & 2 & 4 & 4 & 2 & 3 & 4 & 3 & 3.1 & 3.2 & & \\
\hline & asthma & $n$ & 18 & 32 & 28 & 23 & 20 & 13 & 12 & 8 & 6 & 11 & 121 & 50 & 0.23 & 0.626 \\
\hline & & $\%$ & 2 & 4 & 3 & 3 & 2 & 4 & 4 & 2 & 2 & 4 & 2.9 & 3.1 & & \\
\hline & general & $n$ & 37 & 59 & 56 & 43 & 58 & 27 & 18 & 19 & 18 & 19 & 253 & 101 & 0.16 & 0.685 \\
\hline & & $\%$ & 5 & 7 & 7 & 5 & 7 & 8 & 6 & 6 & 6 & 7 & 6.1 & 6.4 & & \\
\hline Diseases and disor & rders of the & $n$ & 7 & 2 & 4 & 8 & 11 & 5 & 3 & 2 & 4 & 3 & 32 & 17 & 1.25 & 0.264 \\
\hline & & $\%$ & 1 & 0 & 0 & 1 & 1 & 1 & 1 & 1 & 1 & 1 & 0.8 & 1.10 & & \\
\hline Chronic urinary tra & act diseases & $n$ & 1 & 1 & 4 & 4 & 4 & 2 & 2 & 0 & 0 & 1 & 14 & 5 & 0.01 & 0.899 \\
\hline & & $\%$ & 0 & 0 & 0 & 0 & 0 & 1 & 1 & 0 & 0 & 0 & 0.3 & 0.3 & & \\
\hline Permanent CNS da & amage & $n$ & 3 & 4 & 2 & 2 & 2 & 2 & 0 & 1 & 3 & 3 & 13 & 9 & 1.96 & 0.161 \\
\hline & & $\%$ & 0 & 0 & 0 & 0 & 0 & 1 & 0 & 0 & 1 & 1 & 0.3 & 0.6 & & \\
\hline Other diseases & diabetes & $n$ & 6 & 2 & 0 & 2 & 0 & 1 & 3 & 5 & 5 & 3 & 10 & 17 & 16.98 & $<0.001$ \\
\hline & & $\%$ & 1 & 0 & 0 & 0 & 0 & 0 & 1 & 2 & 2 & 1 & 0.2 & 1.1 & & \\
\hline & thyroid & $n$ & 2 & 2 & 5 & 5 & 3 & 4 & 1 & 1 & 5 & 5 & 17 & 16 & 7.24 & $<0.001$ \\
\hline & diseases & $\%$ & 0 & 0 & 1 & 1 & 0 & 1 & 0 & 0 & 2 & 2 & 0.4 & 1 & & \\
\hline & cancer & $n$ & 1 & 0 & 0 & 1 & 0 & 0 & 0 & 0 & 0 & 0 & 2 & 0 & 0.73 & 0.382 \\
\hline & & $\%$ & 0 & 0 & 0 & 0 & 0 & 0 & 0 & 0 & 0 & 0 & 0 & 0 & & \\
\hline & general & $n$ & 9 & 5 & 5 & 8 & 6 & 5 & 6 & 6 & 10 & 8 & 33 & 35 & 19.63 & $<0.001$ \\
\hline & & $\%$ & 1 & 1 & 1 & 1 & 1 & 1 & 2 & 2 & 3 & 3 & 0.8 & 2.2 & & \\
\hline $\begin{array}{l}\text { Number of studen } \\
\text { by specialist medi }\end{array}$ & ts covered & $n$ & 197 & 274 & 237 & 169 & 231 & 127 & 90 & 88 & 93 & 96 & 1108 & 494 & 11.6 & $<0.001$ \\
\hline & & $\%$ & 24 & 32 & 29 & 20 & 27 & 36 & 28 & 26 & 30 & 36 & 26.6 & 31.1 & & \\
\hline
\end{tabular}

Dysfunctions in somatic development among the study group were found in $13.6 \%(n=568)$ of primary school children and $19.3 \%(n=306)$ of middle school students. Among the somatic disorders, excessive weight was the prevailing issue. $4.3 \%(n=178)$ of primary school children and $5.6 \%(n=89)$ of secondary school students were reported as overweight. In contrast, obesity related to $4.4 \%(n=183)$ of primary school children and $8.2 \%(n=131)$ of middle school students. The most common health hazards re- 
lated to school children and adolescents were accidents and injuries. These events were recorded over a period of five years in the group of $4.8 \%(n=200)$ primary school children, and half of those documented accidents and injuries happened at the school site $(2.4 \% ; n=101)$. In the group of middle school students, accidents and injuries occurred in $4.3 \%(n=68)$ of the students, including $1.5 \%(n=24)$ on school grounds.

The most common health problems in the group of chronic diseases diagnosed in both groups of middle school students and primary school students were defects and diseases of the motor organs (Table 2).

Among primary school students, the dominant motor disorders were knee osteoarthrosis and pes planus, which related to $14.5 \%(n=605)$ of the children. In contrast, the most common posture defect among secondary school children was scoliosis (4.7\%; $n=75$ ). Sight defects and diseases were diagnosed in less than $1 / 4$ of middle school students $-22.2 \%(n-353)$, and $15.3 \%(n=639)$ of primary school students. Chronic hearing and speech impediments were diagnosed in $3.4 \%(n=141)$ of primary school children and $0.6 \%(n=9)$ of middle school students.

Respiratory diseases predominated in the group of chronic diseases concerning children and youth and related to $6.1 \%$ $(n=253)$ of primary school children and $6.4 \%(n=101)$ of middle school students. The most frequently diagnosed diseases in this group were allergies manifested by the symptoms of respiratory disease (e.g. Rhinitis) $-3.1 \%(n=130)$ of primary school children and $3.2 \%(n=51)$ secondary school children, and bronchial asthma, identified in $2.9 \%(n=121)$ of primary school pupils and $3.1 \%(n=50)$ of middle school students.

As far as other chronic diseases taken under consideration in the developmental-age population, diabetes occurred less frequently in primary school students $(0.2 \% ; n=10)$ than in middle school students $(1.1 \% ; n=17)$, whereas thyroid diseases occurred in $0.4 \%(n=17)$ of primary school students and $1 \%$ $(n=16)$ of middle school students.

The results show that health problems such as excessive weight and endocrine disorders and visually impaired diseases are significantly more common in middle school children $(p<$ 0.001 ). In contrast, younger children are more likely to be diagnosed with hearing and speech disorders $(p<0.001)$ and of injuries and accidents $(p<0.05)$.

\section{Discussion}

The conducted analyses of the collective report "Collected analysis of students' health status" gathered in Lublin primary school and middle school covering the years 2010-2015 has allowed us to identify the most common health problems in the developing population.

The reported results showed that $44.3 \%$ of primary school pupils and $50.6 \%$ of middle school students had health problems. The studies of Haor et al. [8], conducted among children aged 6 and 10, confirm the frequent diagnosis of health problems in the school group. Health problems in the group of 6 -year-olds concerned $87.1 \%$ of the respondents, whereas in 10 -year-old children, health problems were already present in $93 \%$ of the respondents. On the other hand, research conducted by Braczkowska et al. [7] among the general school population in $2005-2006(n=1,606)$ showed that $73.7 \%$ of the young people had health problems, which may indicate an increase in the incidence of health disorders in older ages. The most common health problems associated with shaping the body posture and intensive growth of the body occurring in the group of pupils of primary school and middle school are static disorders of the motor organs. In our study, this was diagnosed in $26.7 \%$ of the children from primary school and $26.9 \%$ of middle school students. Similar results were reported in the study conducted in 2009-2011 by Noczyńska et al. [9] in Wroclaw $(n=1984)$, which reported posture defects in $20.2 \%$ of the children. The number of static disorders of the motor organs in the developmental-age population is shown in the study by Mastalerz-Migas et al. [10], conducted in the Opolskie voivodeship, which found these disorders in $12.4 \%$ of the studied group. According to Woynarowska and Oblacińska [11], it is estimated that movement disorders affect $10-80 \%$ of the population of Polish children. However, there exist extensive discrepancies in the evaluation of the incidence of postural defects, likely due to a lack of standardized diagnostic criteria and postgraduates of ontogenetic courses. A frequent medical disorder in the group of children tested in Lublin was eye defects. These were diagnosed in $22.2 \%$ of middle school students and $15.3 \%$ of primary school students. In the group of Wroclaw children aged 6.5-9.5 years, visual impairment occurred in $11.8 \%$ of the respondents [9]. In contrast, studies of children aged 7-15 from Poznan confirmed the presence of vision defects in $43 \%$ of the respondents [12]. Comparing the results of own research with other authors, one can notice that with the increase in age in children, the percentage of people with visual impairment also increases. This fact is probably due to the high strain to eyesight during school hours, often accompanied by inadequate lighting and an inadequate environment for an individual's physical development.

As indicated by literature, hearing impairment is the most common defect associated with verbal communication disorders [13]. Czech et al. [14] report that every tenth child of preschool age and every sixth of school age has temporary or permanent hearing loss of mild or moderate severity. Our study indicated the prevalence of this disorder in $3.4 \%$ of children from primary school and $0.6 \%$ of middle school students. A positive tendency is the reduction in the percentage of children with hearing loss in older age groups as a result of activities undertaken, i.e. physiotherapy and speech therapy.

The results of the analysis indicate that somatic developmental disorders, including overweight and obesity, represent a significant health problem in the population of school children. The research lead among school children in Lublin confirmed the occurrence of excessive weight gain in the group of students: $8.7 \%$ of primary school students and $13.8 \%$ of middle school students. A similar situation was described in children aged 6.5-9.5 years in Wroclaw, in which overweight was found in $13.6 \%$ of the respondents [15]. Likewise, a study conducted among 16-year-olds in Oświęcim found overweight and obesity in $7.9 \%$ of the total number of students [7]. On the other hand, the HBSC national report [2] indicates that overweight and obesity occur in every seventh teenager, with a visible decrease in the proportion of adolescents with overweight compared to 2010. This situation is most likely due to implementing educational and preventive measures to counter obesity among young people.

Subsequently, allergic diseases are an increasing health problem among school children. In the presented population, they concern $6.1 \%$ of primary school children and $6.4 \%$ of middle school students. Studies by Braczkowska et al. [7] indicate the occurrence of allergy in $11.7 \%$ of young people at the age of 16 years. Durska et al. [16], who conducted a study among Szczecin middle school students, diagnosed atopy in $23.8 \%$ of the students.

A larger group of children with known allergies were found by Noczyńska et al. [9], who encounter them in $30.1 \%$ of the population aged 6.5-9.5 years in Wroclaw. According to the results of studies conducted in different Polish cities, there are differences in the incidence of allergic diseases, which are largely due to environmental and family factors [16].

The impact of environmental factors on allergies in school-aged children has been confirmed by studies conducted by Miyashita et al., Japan, where the effects of natural disasters on the incidence of allergic diseases, such as asthma and eczema, have been observed [17].

Accidents and injuries are the leading cause of death and disability among children and adolescents aged 0-19 years. In 
the studied group of Lublin pupils, they were recorded over a five year period in $4.8 \%$ of primary school children and $4.3 \%$ of middle school students. Długoń et al. [18], analyzing the epidemiology of injuries among children and adolescents $(n=$ 2245 ) in 2005-2011, found that the largest group of children consulted by medical personnel for trauma were aged 10-14. The places where the injuries most often occurred were playgrounds, at home and at school. According to the HBSC report in 2014, every third teenager suffered at least one injury requiring medical attention, and $17.7 \%$ of adolescents sustained traumas requiring more demanding treatment, including hospitalization [2]. On the other hand, studies conducted among Portuguese school children showed increased traumas in students attending additional afterschool sports activities, such as training [19].

\section{Limitations of the study}

The results of our research were concerned with the analysis of the health problems of primary school and middle school students in Lublin, analyzing reporting documentation conducted by a nurse of the teaching and learning environment. The number of schools being a source for data analysis was limited. In addition, high school students were not included in the study, and thus the most common health problems for adolescents aged 16-19 have not been characterized. Another aspect that should be noted as a limitation of this study is a retrospective analysis of the method based on data from existing documen- tation in the medical school, which introduced some possible shortcomings in statistical analysis of the results. A significant limitation in the analysis of the results was the lack of access to raw data - individual student health records, which enabled the inclusion of more quantitative and qualitative data on the respondents, which would allow for the distribution of variables to be analyzed and more advanced statistical correlations to be implemented. The obtained qualitative data, aggregated from individual years, limited us to determining the frequency of specific problems in groups of students. Future studies should therefore be extended to include a larger number of primary schools and analyze the most common health problems among high school students, as well as the need for an additional diagnostic test.

\section{Conclusions}

The analysis of health problems in primary and middle school students in Lublin in the years 2010-2015 shows that the frequency of health disorders increases with age. The predominant health problems among both primary school students and middle school students are defects and diseases of the motor organs. The most common chronic conditions diagnosed among school children are allergic diseases. Accidents and injuries, on the other hand, are the most common health risks for the developing-age population.

Source of funding: This work was funded by the authors' own resources.

Conflict of interest: The authors declare no conflict of interests.

\section{References}

1. Piekarzewska M, Zajenkowska-Kozłowska A. Zdrowie i zachowanie zdrowotne mieszkańców Polski w świetle Europejskiego Ankietowego Badania Zdrowia (EHIS) 2014 r. Wydział Statystyki Zdrowia Departament Badań Społecznych i Warunków Życia GUS [cited 24.02.2017]. Available from URL: http://stat.gov.pl/obszary-tematyczne/zdrowie/ (in Polish).

2. Mazur J, ed. Zdrowie i zachowania zdrowotne młodzieży szkolnej w Polsce na tle wybranych uwarunkowań socjodemograficznych. Wyniki badań HBSC 2014. Warszawa: Instytut Matki i Dziecka; 2015 (in Polish).

3. Brzeźniak H, Mroczek B, Kotwas A, et al. Analiza wybranych zachowań zdrowotnych oraz samooceny masy ciała szczecińskich gimnazjalistów. Fam Med Prim Care Rev 2015; 17(2): 82-85 (in Polish).

4. Sadowska J, Daniel I. Konsekwencje zdrowotne nieprawidłowości w żywieniu dzieci i młodzieży w wieku gimnazjalnym. Kosmos Probl Nauk Biol 2016; 4(65): 553-561 (in Polish).

5. Szymborski J, ed. Zdrowie dzieci i młodzieży w Polsce. Zarys diagnozy i kierunków poprawy. Warszawa: Wydawnictwo Rządowa Rada Ludnościowa; 2012 (in Polish).

6. Zgliczyński W. Opieka nad dziećmi i młodzieżą w systemie ochrony zdrowia w Polsce. Studia BAS 2014; 2(38): 7-40 (in Polish).

7. Braczkowska B, Cyran W, Braczkowski R, et al. Problemy zdrowotne młodzieży szesnastoletniej - uczniów szkół ogólnokształcących w Oświęcimiu. Probl Hig Epidemiol 2008; 89(3): 359-366 (in Polish).

8. Haor B, Głowacka M, Szczukowska K, et al. Wybrane problemy zdrowotne 6-letnich i 10-letnich uczniów w środowisku nauczania i wychowania. Pielęg XXI w 2014; 4(49): 23-28 (in Polish).

9. Noczyńska A, Zubkiewicz-Kucharska A, Mysłek-Prucnal M, et al. Ocena stanu zdrowia dzieci wrocławskich w wieku 6,5-9,5 lat. Część 2 . Fam Med Prim Care Rev 2014; 16(1): 29-31 (in Polish).

10. Mastalerz-Migas A, Krupa T, Muszyńska A, et al. Epidemiologia wad postawy u dzieci i młodzieży na terenie województwa opolskiego. Fam Med Prim Care Rev 2006; 8(3): 692-694 (in Polish).

11. Woynarowska B, Oblacińska A. Stan zdrowia dzieci i młodzieży w Polsce. Najważniejsze problemy zdrowotne. Studia BAS 2014; 2(38): 41-64 (in Polish).

12. Dalz M, Krzyżaniak A. Wady refrakcji w aspekcie badań przesiewowych w szkole. Now Lek 2004; 73: 366-369 (in Polish).

13. Gryczuk E, Frąc L, Topczewska-Cabanek A, et al. Wiedza rodziców na temat postępowania leczniczego i rehabilitacyjnego u dzieci z niedosłuchem. Fam Med Prim Care Rev 2014; 16(1): 20-24 (in Polish).

14. Czech D, Malicka M, Kott E, et al. Ocena występowania zaburzeń artykulacyjnych u dzieci z nawracającymi infekcjami górnych dróg oddechowych. Otorynolaryngologia 2011; 10(3): 116-120 (in Polish).

15. Noczyńska A, Zubkiewicz-Kucharska A, Mysłek-Prucnal M, et al. Ocena stanu zdrowia dzieci wrocławskich w wieku 6,5-9,5 lat. Część 1 . Fam Med Prim Care Rev 2014; 16(1): 25-28 (in Polish).

16. Durska G, Sałacka A, Hornowska I. Częstość występowania atopii i chorób atopowych w grupie gimnazjalistów ze Szczecina - doniesienie wstępne. Fam Med Prim Care Rev 2009; 11(3): 296-298 (in Polish).

17. Miyashita M, Kikuya M, Yamanaka C, et al. Eczema and asthma symptoms among schoolchildren in Coastal and Inland Areas after the 2011 Great East Japan Earthquake: The ToMMo Child Health Study. J Exp Med 2015; 237(4): 297-305, doi: 10.1620/tjem.237.297.

18. Długoń I, Cichocka J, Gołębiak I, et al. Urazy głowy i kończyn u dzieci jako przyczyna konsultacji w izbie przyjęć wybranego szpitala pediatrycznego. Fam Med Prim Care Rev 2014; 16(1): 16-19 (in Polish).

19. Costa E Silva L, Fragoso MI, Teles J. Physical activity-related injury profile in children and adolescents according to their age, maturation, and level of sports participation. Sports Health 2017; 9(2): 118-125, doi: 10.1177/1941738116686964. 
Tables: 2

Figures: 0

References: 19

Received: 29.04.2017

Reviewed: 05.06.2017

Accepted: 25.07.2017

Address for correspondence:

Katarzyna Kocka, MD, PhD

Zakład Medycyny Rodzinnej i Pielęgniarstwa Środowiskowego

Katedra Onkologii i Środowiskowej Opieki Zdrowotnej

Wydział Nauk o Zdrowiu UM

ul. Staszica 4-6

20-081 Lublin

Polska

Tel.: +48 692977547

E-mail: katarzyna48@op.pl 